\title{
A routine method for the determination of phosphoglucose isomerase activity in body fluid
}

\author{
J. E. HORROCKS, J. WARD, AND J. KING \\ From North Lonsdale Hospital, Barrow-in-Furness, Lancashire
}

SYNOPSIS A simple, rapid colorimetric method for the estimation of phosphoglucose isomerase activity, using the determination of fructose by the method of Roe, Epstein, and Goldstein (1949) ${ }_{\omega}^{\circ}$ is described. An arbitrary fructose standard is advocated and normal values for human serum ands cerebrospinal fluid are presented.

Phosphoglucose isomerase, the trivial name for the enzyme D-glucose-6-phosphate ketol-isomerase, code number 5.3.1.9 (Report of the Commission on Enzymes of the International Union of Biochemistry, 1961) catalyses the isomerization of D-glucose-6phosphate to D-fructose-6-phosphate.

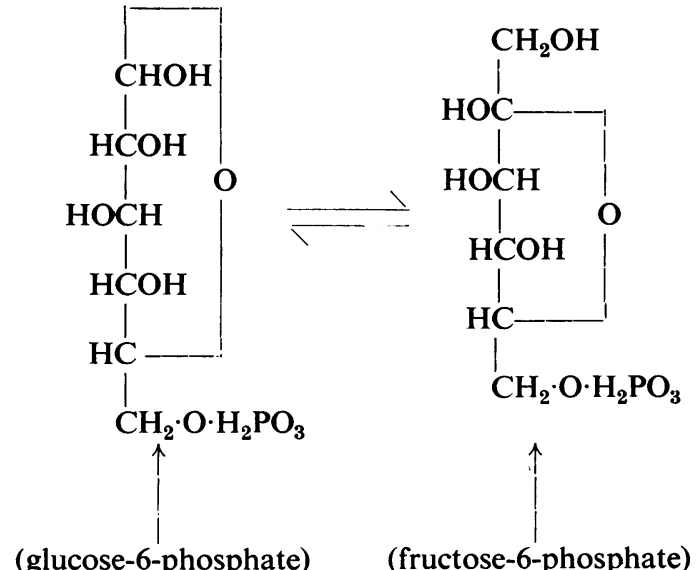

Phosphoglucose isomerase is a widely distributed glycolytic enzyme present in liver, muscle, bone, brain, lung, erythrocytes, and leucocytes in decreasing order of activity. Like other ubiquitous enzymes, activity is increased after myocardial infarction (Siegel and Bing, 1956; White, 1956; Bing, Castellanos, and Siegal, 1957). As with other glycolytic enzymes, such as lactate dehydrogenase and aldoReceived for publication 15 October 1962. lase, in inflammatory effusions (Horrocks, King Waind, and Ward, 1962) the phosphoglucose isomerase activity of the effusion fluid is ofterb greater than that of the serum and is of no value in differentiating between malignant and benigng origin (unpublished observations).

The serum activity is greatly increased in acute hepatitis (Bruns and Jacob, 1954; Bruns, 1957 Bing et al., 1957; Bodansky, Krugman, Ward㐫 Schwartz, Giles, and Jacobs, 1959). Israels and Delory (1956), Israels, Delory, Hnatiuk, and Friesen (1958) and Blanchaer, Green, MacLean, and Hollenberg (1958) found raised activity in myelow cytic leukaemia but not in the leucocytosis of infection or in lymphocytic leukaemia.

Bodansky, Gershten, and Wilson (1954) anç Myers and Bodansky (1957) reported the assay tiक be useful in following progress during palliative treatment for metastatic carcinoma of the brease and also of the prostate (Bodansky, Calitri, ans Wilson, 1955). In this respect, interest in the enzymes has recently been renewed by the work of Jegatheesare and Joplin (1962) who confirm and extend the pref్ vious findings.

The equilibrium of the reaction catalysed favours glucose-6-phosphate, but because of the convenient methods of measuring fructose by the Seliwanot reaction (Roe, 1934; Roe et al., 1949) most seruro enzyme assay techniques have used a substrate of glucose-6-phosphate (Bodansky and Calitri, 1954? Glock, McLean, and Whitehead, 1956; British Drug Houses, 1960). A coupled spectrophotometrio method taking advantage of the favourable equilia brium given by a substrate of fructose-6-phosphat 8 appeared possible. Purified glucose-6-phosphate 
dehydrogenase and coenzyme II (nicotinamideadenine-dinucleotide phosphate, N.A.D.P.) included in the reaction mixture would oxidize the glucose-6phosphate formed and enable the reaction to be monitored by following the increase in optical density at $340 \mathrm{~m} \mu$, at which wavelength the reduced coenzyme has a peak absorption. However, this procedure is complicated by the presence in human blood of 6-phosphogluconate dehydrogenase which also utilizes N.A.D.P. in the oxidation of 6-phosphogluconate, some quantity of which would result from the secondary reaction. 6-Phosphogluconate is also reported to be inhibitory to phosphoglucose isomerase (Parr, 1956). This approach, although used by Rose and O'Connell (1961) in isotope studies with purified enzyme preparations, appears to be too expensive and too complex for routine purposes.

The method of Bodansky and Calitri (1954) only requires incubation for 30 minutes at $37^{\circ} \mathrm{C}$. using an acetate-veronal buffer, $p \mathrm{H} 7 \cdot 4$, but includes protein precipitation. The modified procedure (British Drug Houses, 1960) of Glock et al. (1956) omits protein precipitation but requires 60 minutes' incubation at $37^{\circ} \mathrm{C}$. in a glycylglycine buffer, $p \mathbf{H}$ 7.6. Further, this latter method only measures activity in the normal range of human serum and tests must be repeated using smaller quantities of specimen or shorter periods of incubation if raised serum activity is encountered. Grave miscalculations of phosphoglucose isomerase activity are also possible unless a complete specimen and reagent blanks are included.

A point which makes difficult the comparison of results published by different workers and leads to much confusion is the relative chromogenicity of fructose and fructose-6-phosphate. The situation is also complicated by the fact that although the original method of Roe (1934) used colour development by heating at $80^{\circ} \mathrm{C}$. for eight minutes, and the time was extended to 10 minutes in the later procedure (Roe et al., 1949), many workers have heated for 15 minutes to develop the cherry red colour. Roe and his colleagues do not mention any difference in colour intensity between fructose and its phosphate esters; indeed the 1-ester and 1,6 diester are rapidly hydrolysed by heating in the strongly acid solution. Bodansky (1953), using the original Roe method, found that fructose-6-phosphate, which is stable under the conditions of colour development, only gives $61 \%$ of the colour given by fructose, and Glock et al. (1956) give a value of $65 \%$ measuring the optical density at $490 \mathrm{~m} \mu$. Hers, Beaufays and De Duve (1953), using a modification of the method of Roe et al. (1949), gave a value of $82 \%$ of that of fructose for the chromogenicity of fructose-6phosphate whereas Dische (1951) found that both fructose and fructose-6-phosphate gave equal colour intensity. Kahana, Lowry, Schulz, Passonneau, and Crawford (1960), using enzymatically prepared fructose-6-phosphate, agree with Dische when using the original procedure but found that fructose6-phosphate actually gave 5\% more colour than fructose when the latter method was used, regardless of whether heating is for eight or 15 minutes.

Fructose-6-phosphate of analytical grade purity is not obtainable and therefore a secondary standard of fructose must be used. It is proposed that this fructose standard be used without any modification or consideration of the possible relative chromogenicity of fructose and fructose-6-phosphate. This is arbitrary but at least a permanent and conparable measure of activity is established rather than one which is continually varying with empirical figures given by workers using compounds of purity which are unknown and not reproducible. Further, in actual assays, if at the end of the reaction period proteins are precipitated by means of zinc sulphate followed by barium hydroxide, a procedure which results in fructose-6-phosphate, but not fructose, being adsorbed to the precipitate, a colour reaction is still obtained. This indicates that some (enzymic) hydrolysis of fructose-6-phosphate occurs and therefore in actual fact an unknown proportion of both the ketose and its 6-ester is present in the reaction mixture which further justifies the use of an arbitrary fructose standard.

A study of the kinetics of phosphoglucose isomerase activity was undertaken in the hope that a simple, rapid method of assay applicable to body fluids might be elaborated.

\section{REAGENTS}

M10 BORATE BUFFER ( $p \mathrm{H} 7 \cdot 8)$ Dissolve $6.184 \mathrm{~g}$. boric acid (AR) and $7.456 \mathrm{~g}$. potassium chloride (AR) in water, add $53 \mathrm{ml}$. N/10 $\mathrm{NaOH}$ and make up to 1 litre with water.

BUFFERED SUBSTRATE Dissolve $3 \mathrm{mg}$. disodium glucose6-phosphate per millilitre of buffer. Use on the same day as prepared.

$30 \%$ HYDROCHLORIC ACID Make up $850 \mathrm{ml}$. hydrochloric acid (AR) to 1 litre with water.

RESORCINOL-THIOUREA REAGENT Resorcinol (AR), and $250 \mathrm{mg}$. thiourea dissolved in $100 \mathrm{ml}$. glacial acetic acid (AR). Store in a brown bottle and discard when the solution becomes discoloured.

COLOUR REAGENT Mix together in the proportions 7:1:1 30\% hydrochloric acid, resorcinol-thiourea reagent, and water. Use on the same day as prepared. 
STANDARD SOLUTION Fructose, $54 \mathrm{mg}$., is dissolved in 1 litre of $0.25 \%$ benzoic acid. Of this $1 \mathrm{ml}$. is equivalent to 100 milli international units under the assay conditions. The solution is stable for months at room temperature.

\section{PROCEDURE}

Into two tubes labelled 'test' and 'blank' pipette $1 \mathrm{ml}$. of buffered substrate and place in the water bath at $37^{\circ} \mathrm{C}$. for a few minutes to reach bath temperature, then add $0.1 \mathrm{ml}$. of serum to the 'test' tube and begin timing. Exactly 30 minutes after addition of the specimen remove the tubes from the bath, add $0.1 \mathrm{ml}$. specimen to 'blank' tube and $9 \mathrm{ml}$. of colour reagent to both. Place both tubes in the $75^{\circ} \mathrm{C}$. water bath. At the same time standard and standard blank tubes containing respectively $1 \mathrm{ml}$. of standard and $1 \mathrm{ml}$. of water treated with $9 \mathrm{ml}$. of colour reagent are also placed in the bath. After 15 minutes at $75^{\circ} \mathrm{C}$. the tubes are immediately cooled in cold running water and the pink-red colour read in the next few minutes using a blue-violet filter or transmission at $410 \mathrm{~m} \mu$.

Since $0.1 \mathrm{ml}$. of specimen is used with a 30 -minute reaction period and the standard is $0.0003 \mathrm{M}$ this is equivalent to

$\frac{0.0003 \times 1000}{30} \times \frac{1}{0.1} \mu$ mole $/ \mathrm{min} . / \mathrm{ml}$., i.e., international

or $100 \mathrm{~m} \mu \mathrm{mole} / \mathrm{min} . / \mathrm{ml}$. or $\mathrm{m}$ i.u.

The calculation of activity is then given by

$$
\frac{\text { (Test-blank) }}{\text { (Standard-blank) }} \times 100 \mathrm{~m} \text { i.u. }
$$

King and Campbell (1961), in introducing the international units, proposed that activity be expressed per litre of specimen. The Report of the Commission on Enzymes of the International Union of Biochemistry (1961), however, recommends that activity be expressed per millilitre of specimen. Activity expressed in $\mathrm{m}$ i.u. per millilitre is numerically the same as i.u. per litre.

The development of colour is sensitive to time and temperature of incubation as well as to the purity of the reagents used. It is therefore strongly recommended that where possible AR grade reagents should be used and a standard carried through the colour development with each assay or batch of assays. The use of a standard curve cannot be recommended with this test. A linear relationship exists between colour development and enzyme activity up to approximately $300 \mathrm{~m}$ i.u. under the conditions prescribed. Specimens with greater activity should be repeated using either a smaller quantity or shorter period of incubation and the results adjusted accordingly.

Since erythrocytes contain approximately 150 times the phosphoglucose isomerase activity of serum, which is very similar to the ratio for lactate dehydrogenase activity, visible haemolysis makes a sample useless for phosphoglucose isomerase assay (King and Waind, 1961). Heller, Weinstein, West, and Zimmerman (1960) found consistently lower activity in platelet-poor plasma, approximately $60 \%$ that of serum. Very variable results were found with plasma, irrespective of the anticoagulane used, and serum is recommended.

For assay of phosphoglucose isomerase activity in: cerebrospinal fluid, the reagents are unchanged bu的 the substrate contains $5 \mathrm{mg}$. glucose-6-phosphate (disodium salt) per millilitre of buffer. Of this buffered substrate $0.6 \mathrm{ml}$. and $0.5 \mathrm{ml}$. of cerebrospinal fluid are incubated and the assay continued as for serum. The calculation is the same as previously shown which in this case makes the standard equivalent to $20 \mathrm{~m}$ i.u.

NORMAL VALUES

With 100 sera from normal healthy adults, aged from 19 to 60 years, a range of 13.5 to $86 \mathrm{~m}$ i.u., with a mear of $46.5 \mathrm{~m}$ i.u. and standard deviation \pm 16.5 , was found? Ninety-eight per cent of these values was covered by the range 13.5 to $78 \mathrm{~m}$ i.u., and it is suggested that activity outside this range should be considered abnormain (Wootton and King, 1953).

In the first days of life much higher levels are foundo Assay of 36 cord blood sera gave values from 45 to $17 \mathrm{~L}$ $m$ i.u. with a mean of 90 and standard deviation $\pm 33 z$ In this series readings were also taken at $520 \mathrm{~m} \mu$ which gave a range 45 to $169 \mathrm{~m}$ i.u., mean 91 and standard deviation \pm 32 , thereby demonstrating the reproduciso bility of the method at either wavelength.

With cerebrospinal fluid from patients with no demon strable central nervous system lesions activity from $0 \cdot P$ to $6.2 \mathrm{~m}$ i.u. has been found and this is proposed as as provisional normal range although it is much lowef than that found by Bruns, Jacob, and Weverinck (1956)?

\section{RESULTS}

A fairly wide range of $p \mathrm{H}$ optima extending from $p \mathrm{H} 7 \cdot 2$ to 8.4 is observed using phosphate, tris, and. borate buffers. Higher activity and a more linea relationshiop between activity and time and activityo and enzyme concentration is found with borate. buffer, but we are unable to confirm the observation of Alvarado and Sols (1957) that in the presence of 3 M10 borate the reaction equilibrium is shifted ino favour of fructose-6-phosphate.

Results for the composition of the equilibrium mixture are in agreement with those of previous authors, that is, approximately $40 \%$ isomerization with a fructose-6-phosphate chromogenicity of $61 \%$ (Bodansky, 1953) to $25 \%$ isomerization with equaN fructose and fructose-6-phosphate chromogenicity (Kahana et al., 1960). Zero order kinetics are observed up to $5 \%$ isomerization on the latter assumption.

The amount of substrate that may be used is limited by spontaneous non-enzymic isomerization $\bar{b}$ which, with increasing substrate concentration $\mathbb{\mathbb { D }}$ results in very high optical densities for the assay blanks. Under the conditions finally adopted for time of incubation and quantity of specimen the 
optimal substrate concentration resulted in blank values sufficiently low to permit of tests being recorded in the most sensitive range of absorptiometric apparatus, that is, the optical density range of 0.9 to 0.8 .

The colour reagents of Roe (1934) and of Roe et al. (1949) were investigated and the latter found to give more reproducible results, particularly when colour development was for 15 minutes at $75^{\circ} \mathrm{C}$. as recommended by Hers et al. (1953). Typical absorption spectra are shown in Fig. 1 whence it is seen that the maximum difference in optical density between test and blank is obtained at $410 \mathrm{~m} \mu$. Furthermore, readings at $410 \mathrm{~m} \mu$ are more stable with respect to time than at $520 \mathrm{~m} \mu$ as previously used. At $410 \mathrm{~m} \mu$ the optical density of test, blank, and standard increase almost equally, about $8 \%$ per hour. At

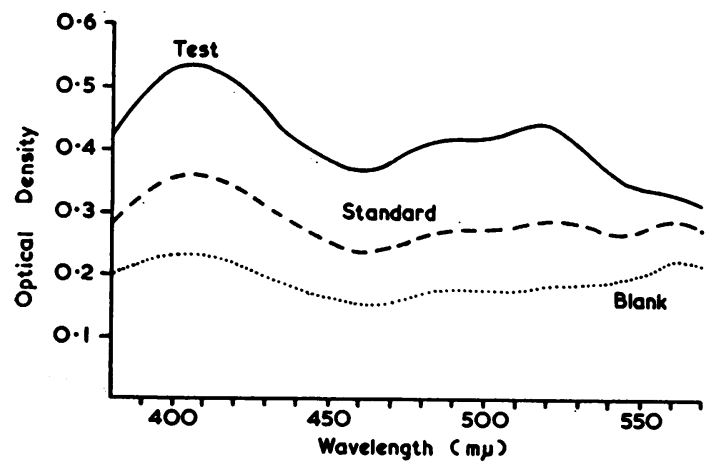

FIG. 1. Typical absorption spectra.

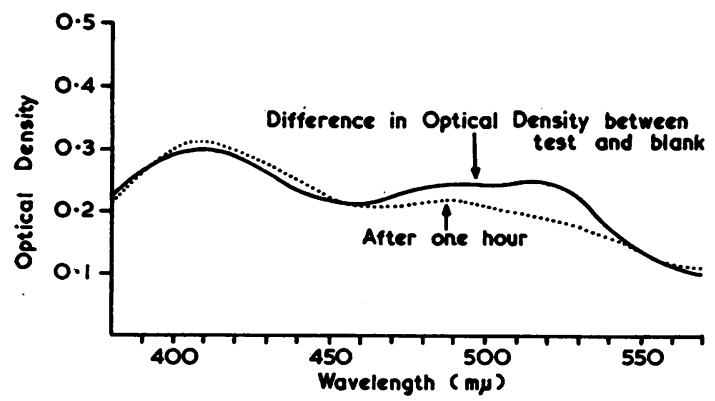

FIG. 2. Behaviour of test and blank at $520 \mathrm{m \mu}$.
$520 \mathrm{~m} \mu$, however, the test optical density decreases some $14 \%$ per hour while the blank value increases slightly. This behaviour is illustrated in Fig. 2.

These studies result in an assay method which is suitable for use in routine hospital laboratories, requiring neither skill nor equipment beyond that which is accepted as essential, with the possible exception of a $75^{\circ} \mathrm{C}$. water bath.

\section{REFERENCES}

Alvarado, F., and Sols, A. (1957). Biochim. biophys. Acta (Amst.), 25, 75 .

Bing, R. J., Castellanos, A., and Siegel, A. (1957). J. Amer. med. Ass., 164, 647.

Blanchaer, M. C., Green, P. T., Maclean, J. P., and Hollenberg, M. J. (1958). Blood, 13, 245.

Bodansky, O. (1953). J. biol. Chem., 202, 829.

—, and Calitri, D. (1954). Ibid., 7, 1191.

- - - , and Wilson, C. (1955). Ibid., 8, 1087.

-, Gershten, B., and Wilson, C. (1954). Ibid.. 7, 1200.

-, Krugman, S., Ward, R., Schwartz, M. K., Giles, J. P., and Jacobs, A. M. (1959). Amer. J. Dis. Child., 98, 166.

British Drug Houses (1960). Assay Methods for Serum Enzymes., 7.

Bruns, F. H. (1957). Clin. chim. Acta, 2, 257.

- and Jacob, W. (1954). Klin. Wschr., 32, 1041.

,-- , and Weverinck, F. (1956). Clin. chim. Acta., 1, 63.

Dische, Z. (1951). In Phosphorus Metabolism. A symposium on the role of phosphorus in the metabolism of plants and animals, edited by W. D. McElroy and B. Glass, p. 171. Hopkins, Baltimore.

Glock, G. E., McLean, P., and Whitehead, J. K. (1956). Biochem. J., $63,520$.

Heller, P., Weinstein, H. G., West, M., and Zimmerman, H. J. (1960). J. Lab. clin. Med., 55, 425.

Hers, H. G., Beaufays, H., and DeDuve, C. (1953). Biochim. biophys. Acta (Amst.), 11, 416.

Horrocks, J. E., King, J., Waind, A. P. B., and Ward, J. (1962). J. clin. Path., 15, 57.

Kahana, S. E., Lowry, O. H., Schulz, D. W., Passonneau, J., and Crawford, E. J. (1960). J. biol. Chem., 235, 2178.

Israels, L. J., and Delory, G. E. (1956). Brit. J. Cancer., 10, 318.

- - Hnatiuk, L., and Friesen, E. (1958). Blood, 13, 79.

Jegatheesan, K. A., and Joplin, G. F. (1962). Brit. med. J., 1, 831.

King, E. J., and Campbell, D. M. (1961). Clin. chim. Acta (Amst.), 6, 301 .

King, J., and Waind, A. P. B. (1961). Lancet, 1, 1408.

Myers, W. P. L., and Bodansky, O. (1957). Amer. J. Med., 23, 804. Parr, C. W. (1956). Nature (Lond.), 178, 1401.

Report of the Commission on Enzymes of the International Union of Biochemistry (1961). Pergamon Press, New York.

Roe, J. H. (1934). J. biol. Chem., 107, 15.

Epstein, J. H., and Goldstein, N. P. (1949). J. biol. Chem., 178, 839.

Rose, I. A., and O'Connell, E. L. (1961). Ibid., 236, 3086.

Siegel, A., and Bing, R. J. (1956). Proc. Soc. exp. Biol. (N.Y.), 91, 604.

White, L. P. (1956). New Engl. J. Med., 255, 984.

Wootton, I. D. P., and King, E. J. (1953). Lancet, 1, 470. 